\title{
Haemorrhage Detection and Classification: A Review
}

\author{
Priyanka Jaware*, Mrs. Shubhangi Borkar** \\ *Department of E\&TC, Nagpur Institute of Technology, Nagpur \\ ** Department of E\&TC, Nagpur Institute of Technology, Nagpur
}

\begin{abstract}
In Indian population, the count of diabetic peoples gets increasing day by day. Due to improper balance of insulin in the human body causes Diabetic. The most common symptom of the person with diabetes is diabetic retinopathy, which leads to blindness. The effect due to DR can reduce by early detection of Haemorrhages and treated at an early stage. In recent year, there is an increased interest in the field of medical image processing. Many researchers have developed advanced algorithms for Haemorrhage detection using fundus images. In proposed paper, we discuss various methods for Haemorrhage detection and classification.
\end{abstract}

Keywords : Diabetic Retinopathy, Feature Extraction NonHaemorrhage, KNN, SVM

\section{INTRODUCTION}

Diabetic retinopathy is the leading cause of the blindness. The population of the diabetic patient in the world is increasing day by day. The diabetic causes are not seen until the disease proceeds to severe effects on some of the vital parts of the body including eye and liver. It damages the vascular system in the eye due to excess amount of glucose circulating through the small blood vessels. There are several types of injuries such as Haemorrhages, Microaneurysms, exudates, cotton wools, etc. the effect of diabetic retinopathy. To circumvent the DR, early detection is necessary. Usually, Doctors recognize DR based on the externally visible feature like the swollen blood vessel, small Haemorrhages, exudates, Microaneurysms and texture of the eye. The first detectable step of the DR is microaneurysms and Haemorrhages. Therefore, Haemorrhage detection is important for early detection of DR.

The diabetic retinopathy is divided into two stages Non-Proliferative Diabetic Retinopathy (NPDR) and Proliferative Diabetic Retinopathy ( PDR) [1]. The diabetic retinopathy starts with NPDR, firstly Haemorrhage was found. The effect of diseases increases with the blockage of retinal vessels.

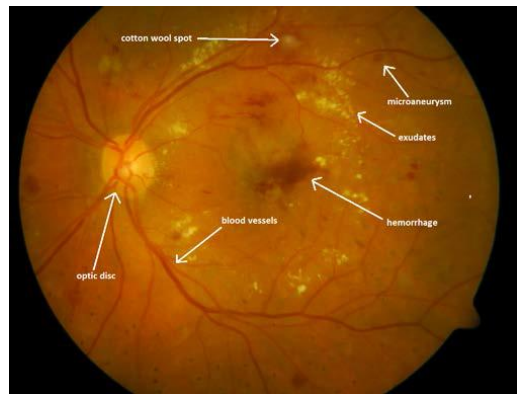

Fig. 1 Retinal image containing different types of lesion
The generalized block diagram for automatic Haemorrhage detection is shown in fig. 2.

\section{a. Database}

The first step of the system is the collection of the database. There are various online databases for fundus image are available such as DIARETDB1, DRIVE, HRF, etc.

\section{b. Preprocessing}

The image is taken as input from the database. The color is in RGB format. The red channel is relatively bright and vascular structure can become easily visible but have little contrast than green channel while the blue channel is too noisy. So by eliminating blue channel and taking advantage of the red and green channel, the image is reconstructed and enhance [2] [3].

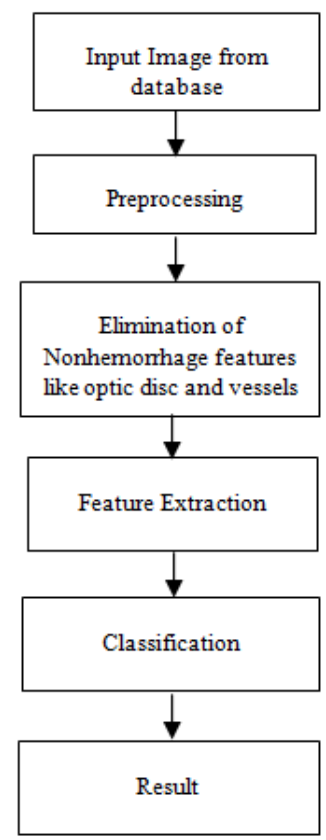

Fig. 2. Flow chart of Haemorrhage detection 


\section{c. Elimination of Non-Haemorrhage Features}

The fundus camera usually captures a noisy and nonuniform illuminated images. Fundus images have a bright spot at optic disc. This may make a difficult to find out the Haemorrhages. Likely blood vessels have a similar colored as Haemorrhage, so it has also made difficult to find Haemorrhages. So vessels and optic disc removal are an important step. The traditional method is to adjust the brightness and intensify the contrast between a region of interest and background [4] [5]. Most of the nonHaemorrhage features elimination techniques based on the morphological processing Bae et al. [4] Propose two methods to process a fundus image. Firstly, the green channel is processed using HSV brightness correction to make uniform intensity over the fundus image. Secondly, CLAHE technique is used to enhance the contrast of an image. Zhang and Fan [6] presented an algorithm to detect spot lesion using multiscale morphological processing. Scalebased lesion validation removed vessels and overdetection. Matei et al. [7] and Langroudi et al. [8] Present thresholding and morphological operation to detect blood vessels in fundus image. Another approach proposed by Acharya et al. [9] based on the morphological operation and 'Ball' shaped structuring element. The Haemorrhages were detected by subtracting blood vessels from Haemorrhage candidates.

Another approach is to the removal of the optic disc from fundus image. Marwan and Eswaran [10] proposed the method to remove the optic disc from fundus image using the median filter. Center of the image is key to detect an optic disc. After detecting optic disc, the median filter is applied to it. Median filter, fill up the blood vessels inside the optic disc which made easy to remove the optic disc by using thresholding. H. A. Hassan et al. [11] proposed automatic optic disc removal in fundus image using iterative morphological operations. The morphological operation such as erosion and dilation enhance the image. A Genetic algorithm was used for optic disc removal. This algorithm is proposed by G. Ferdic Mashak Ponnaiah et al.[12]. In this work, they introduced the method to remove false hard exudates and improve DR accuracy. Using a genetic algorithm, the Optic disc is detected and removed.

\section{d. Feature Extraction}

Feature selection is a significant step for image classification. Without proper selection of the feature, classifier accuracy can't be improved. Mostly, researcher extracted feature using GLCM and Splat feature. The detailed method is explained below.

\section{- Splat Features:}

Splat features are extracted by distribution and aggregation of splat-based on pixel collection. The each extracted splat indicates the relation between its and neighbor splat. Some of the splat features are color, Gaussian filter bank, dog filter bank, splat area, texture, contrast, splat orientation, local texture filter, correlation, splat extent, energy, homogeneity.

\section{- Gray Level Co-Occurrence Matrix (GLCM):}

GLCM mostly extract feature based on the texture information. The number of gray levels is equal to the number of row and columns. The matrix elements is a relative frequency in which two pixels are separated by pixel distance and particular angle.

The different papers are reviewed in Table 1

\section{e. Classification}

There are different techniques to classify the Haemorrhages. In [2], the Haemorrhages were classified by area, aspect ratio, compactness, etc. In most of the research paper, Haemorrhage was classified using SVM, KNN, etc.

\section{- SVM}

Support vector machine classifier is a supervised linear binary classifier. It analyzes the input feature data and possible outputs. So, it predicted the given input testing data and classified into two groups.

Assuming given some training data $\mathrm{D}$, a set of $\mathrm{n}$ points in the form

$\mathrm{D}=\{(\mathrm{Xi}, \mathrm{yi}) \mid \mathrm{Xi} € \mathrm{Rp}$, yi $€\{0,1\}\} \mathrm{i}=1$ to $\mathrm{n}$.

Where, yi is either 1 or 0 , indicating the class to which the point $\mathrm{xi}$ belong each $\mathrm{Xi}$ is $\mathrm{p}$ - dimensional real vector.

$$
\mathrm{W} . \mathrm{X}-\mathrm{b}=0
$$

Maximum - margin - hyperplane (3.2) that divides the point $y i=1$ from $y i=-1$ in the set of points $X$

$$
\text { W. } X_{i}-b \geq 1
$$

If the training data are linearly separable, hyperplanes are selected by separating the data using different classes that are represented by both (3.3) \& (3.4)

$$
\text { W. } X_{i}-b \leq 1
$$

The above classifier classifies the Haemorrhages into normal and Haemorrhage affected the retina. 


\section{- KNN}

KNN classifier is widely used for classification of the different image. It is also used in the field of image processing and pattern recognition. It is mostly used because of its simplicity. In this algorithm distance between training and testing instances were measured. The Minkowski and Euclidean distance are usually used. $\mathrm{K}$ represents the nearest neighbor. In [13] the value of $\mathrm{k}$ is selected as 101 for better accuracy. In [14] author chooses a set of 20 images are taken from a DRIVE database for training and 1200 images from MESSIDOR database [15]

\section{- Neural Network}

The neural network is another approach to classifying the Haemorrhages. The popular method is the backpropagation. It is supervised ANN. The architecture of the classifier plays an important role in determining the accuracy of classification.

The general Artificial neural network consists of three layers, i.e. Input layer, Hidden layer and the output layer. The weight is the other factor responsible for deciding the probability to detect output correctly. The error between the desired output and the target is calculated and use as a feedback to correct it. This process is continuing process until getting the expected output.
D. Usher et al. [16] used the neural network for classification of microaneurysm. It uses 500 images for training purpose, while 773 images were tested using ANN.

Learning vector quantization approach for Haemorrhage classification is proposed by $\mathrm{M}$. Garcia [17]. A small $32 \times 32$ window is used for feature extraction. 29 features were extracted and were trained and testing using MLP. 50 images were used for testing.

The Comparative analysis of different methods is tabulated below in Table I

\section{CONCLUSION}

The Haemorrhage detection is a challenging task because of variation in the background. Similarly, Haemorrhage detection may difficult due to the confusion of different component present in the fundus image like blood vessels, microaneurysms, fovea. In this paper, we reviewed existing Haemorrhage detection methods so that based on this method researcher can implement a better Haemorrhage detection system.

Table 1. Comparative Analysis of different methods

\begin{tabular}{|c|c|c|c|c|c|c|}
\hline Author & Technique & Database Used & Features & $\begin{array}{c}\text { Classifi } \\
\text { er }\end{array}$ & Results & $\overline{\text { Advantage }}$ \\
\hline $\begin{array}{l}\text { Malay } \\
\text { Kishore } \\
\text { Dutta et } \\
\text { al. [18] }\end{array}$ & $\begin{array}{l}\text { Region Based } \\
\text { Detection }\end{array}$ & - & Area & - & $\begin{array}{l}\text { It gives good result } \\
\text { for classifying Non- } \\
\text { Proliferative } \\
\text { Diabetic } \\
\text { Retinopathy }\end{array}$ & $\begin{array}{l}\text { It has good accuracy, } \\
\text { avoids redundancy in } \\
\text { computation. }\end{array}$ \\
\hline $\begin{array}{l}\text { Saumitra } \\
\text { Kumar } \\
\text { Kuri et al. } \\
{[19]}\end{array}$ & $\begin{array}{l}\text { Gabor Filter } \\
\text { with Local } \\
\text { Entropy } \\
\text { Thresholding }\end{array}$ & DRIVE & $\begin{array}{l}\text { Local entropy } \\
\text { using GLCM }\end{array}$ & - & $\begin{array}{lr}\text { It gives } & 97.72 \% \\
\text { accuracy } & \text { and } \\
98.15 \% & \text { sensitivity } \\
\text { respectively }\end{array}$ & $\begin{array}{l}\text { It have maximum } \\
\text { true positive rate and } \\
\text { reduce false vessels } \\
\text { detection in fundus }\end{array}$ \\
\hline $\begin{array}{l}\text { Syna } \\
\text { Song et al. } \\
{[20]}\end{array}$ & $\begin{array}{l}\text { Vessels } \\
\text { Elimination } \\
\text { and Noise } \\
\text { Elimination }\end{array}$ & $\begin{array}{c}\text { fundus images } \\
\text { fromBhumibol } \\
\text { Adulyadej Hospital }\end{array}$ & Color & - & $\begin{array}{lr}\text { It gives } & \text { good } \\
\text { accuracy } & \text { and } \\
\text { preciseness. } & \end{array}$ & $\begin{array}{l}\text { Technique used to } \\
\text { eliminate MA } \\
\text { (microaneurysms) } \\
\text { and certain small } \\
\text { noise. }\end{array}$ \\
\hline $\begin{array}{l}\text { Asra } \\
\text { Ashraf et } \\
\text { al. [21] }\end{array}$ & $\begin{array}{c}\text { Retinal } \\
\text { Whitening }\end{array}$ & $\begin{array}{l}\text { Own database from } \\
\text { AFIO Hospital } \\
\text { Rawalpindi }\end{array}$ & $\begin{array}{l}\text { discriminating } \\
\text { features }\end{array}$ & SVM & $\begin{array}{l}\text { It is a novel method } \\
\text { for automated } \\
\text { diagnosis of } \\
\text { malarial retinopathy } \\
\text { by detecting retinal } \\
\text { whitening, cotton } \\
\text { wool spots and } \\
\text { Haemorrhages } \\
\text { cases. }\end{array}$ & $\begin{array}{l}\text { It gives good } \\
\text { accuracy, sensitivity, } \\
\text { and specificity. }\end{array}$ \\
\hline $\begin{array}{l}\text { Jaykurnar } \\
\text { Lachure et } \\
\text { al. [22] }\end{array}$ & $\begin{array}{l}\text { Morphological } \\
\text { Operations } \\
\text { and Machine } \\
\text { Learning } \\
\text { (SVM and } \\
\text { KNN } \\
\text { classifier) }\end{array}$ & $\begin{array}{l}\text { Messidor, DB- } \\
\text { dataset }\end{array}$ & $\begin{array}{l}\text { GLCM and } \\
\text { Structural } \\
\text { features }\end{array}$ & & $\begin{array}{l}\text { The method detects } \\
\text { both exudates and } \\
\text { microaneurysms. } \\
\text { The SVM gives } \\
\text { better performance } \\
\text { over KNN classifier. }\end{array}$ & $\begin{array}{l}\text { As combined dataset, } \\
\text { our specificity is } \\
100 \% \text {, and sensitivity } \\
\text { is more than } 90 \% \text { for } \\
\text { SVM }\end{array}$ \\
\hline $\begin{array}{l}\text { Malay } \\
\text { Kishore }\end{array}$ & $\begin{array}{l}\text { Edge-Based } \\
\text { Method \& }\end{array}$ & & & & $\begin{array}{l}\text { The combination of } \\
\text { these approaches }\end{array}$ & $\begin{array}{lr}\begin{array}{l}\text { This } \\
\text { better }\end{array} & \text { accuracy } \\
\end{array}$ \\
\hline
\end{tabular}




\begin{tabular}{|c|c|c|c|c|c|c|}
\hline $\begin{array}{l}\text { Dutta et. } \\
\text { Al. [18] }\end{array}$ & $\begin{array}{c}\text { Strategic } \\
\text { Thresholding }\end{array}$ & & & & $\begin{array}{l}\text { based on the } \\
\text { threshold and edge } \\
\text { detection helps in } \\
\text { eliminating all } \\
\text { possible types of } \\
\text { noises leading to } \\
\text { false exudates that } \\
\text { may have crept in. }\end{array}$ & $\begin{array}{l}\text { without } \\
\text { compromising the } \\
\text { computational time. }\end{array}$ \\
\hline $\begin{array}{l}\text { T. Ruba et } \\
\text { al. [23] }\end{array}$ & classifier & MESSIDIOR & & SVM & $\begin{array}{ll}\text { It gives } & \text { good } \\
\text { Correctness, } & \\
\text { Sensitivity, } & \text { and } \\
\text { Specificity. } & \end{array}$ & $\begin{array}{l}\text { This method is } \\
\text { automated and } \\
\text { simple; it detects } \\
\text { symptoms faster. It } \\
\text { works effectively } \\
\text { even on a poor } \\
\text { computing system }\end{array}$ \\
\hline $\begin{array}{l}\text { Amol } \\
\text { Bhatkar[2 } \\
\text { 4] }\end{array}$ & $\begin{array}{l}\text { Discrete } \\
\text { Cosine } \\
\text { Transform } \\
\text { (DCT) }\end{array}$ & DIARETDB0 & $\begin{array}{l}\text { Entropy, mean, } \\
\text { standard } \\
\text { deviation, } \\
\text { average, Euler } \\
\text { number, contrast, } \\
\text { correlation, and } \\
\text { energy } \\
\text { homogeneity }\end{array}$ & MLPNN & $\begin{array}{l}\text { Detecting accuracy } \\
\text { is } 100 \%\end{array}$ & $\begin{array}{l}\text { Classification } \\
\text { accuracy of multi- } \\
\text { layer perceptron is } \\
\text { Good. }\end{array}$ \\
\hline $\begin{array}{l}\text { Vijay } \\
\text { Mane, } \\
\text { Ramish B } \\
\text { Kawadiw } \\
\text { ale, D. V. } \\
\text { Jadhav[25 } \\
\text { ] }\end{array}$ & $\begin{array}{l}\text { Local entropy } \\
\text { thresholding, } \\
\text { Length } \\
\text { filtering }\end{array}$ & DIARETDB1 & $\begin{array}{l}\text { Area, aspect } \\
\text { ratio, } \\
\text { eccentricity, } \\
\text { mean intensity, } \\
\text { standard } \\
\text { deviation, major } \\
\text { axis, minor axis, } \\
\text { compactness, } \\
\text { equivalent } \\
\text { diameter, } \\
\text { roundness }\end{array}$ & SVM & $\begin{array}{l}\text { Sensitivity is } \\
96.42 \% \text {, specificity } \\
\text { is } 100 \% \text {, Accuracy } \\
\text { is } 96.62 \%\end{array}$ & $\begin{array}{l}\text { The proposed } \\
\text { method performs } \\
\text { very well in } \\
\text { detecting red lesions } \\
\text { as compared to } \\
\text { existing methods }\end{array}$ \\
\hline $\begin{array}{l}\text { Syna } \\
\text { Sreng, } \\
\text { Noppadol } \\
\text { Maneerat, } \\
\text { Don } \\
\text { Isarakorn } \\
\text { [26] }\end{array}$ & $\begin{array}{l}\text { Maximum } \\
\text { entropy } \\
\text { thresholding } \\
\text { method, } \\
\text { median } \\
\text { filtering, } \\
\text { contrast } \\
\text { limited } \\
\text { adaptive } \\
\text { histogram } \\
\text { equalization, } \\
\text { Otsu } \\
\text { thresholding, } \\
\end{array}$ & - & Area, radius, & & $\begin{array}{l}\text { The result from the } \\
\text { ophthalmologist } \\
\text { shows that } 90 \% \text { of } \\
\text { HEs detections were } \\
\text { successful with the } \\
\text { average of } \\
\text { processing time is } \\
6.23 \text { seconds per } \\
\text { image. }\end{array}$ & $\begin{array}{l}\text { Given a success rate } \\
\text { of } 90 \% \text { with the } \\
\text { average } \\
\text { processing time is } \\
6.23 \text { seconds per } \\
\text { image on HEs } \\
\text { detection, the } \\
\text { proposed method is } \\
\text { about to reach the } \\
\text { requirement for the } \\
\text { real practical } \\
\text { software in the } \\
\text { hospital }\end{array}$ \\
\hline $\begin{array}{l}\text { Priyakshi } \\
\text { Bharali, } \\
\text { Jyoti } \\
\text { Prakash } \\
\text { Medhi } \\
\text { and Dr. } \\
\text { S.R. } \\
\text { Nirmala } \\
\text { [27] }\end{array}$ & $\begin{array}{l}\text { CLAHE, } \\
\text { median and } \\
\text { average } \\
\text { filtering, } \\
\text { Region } \\
\text { growing, } \\
\text { Niblack's } \\
\text { thresholding, }\end{array}$ & $\begin{array}{l}\text { HRF, DIARETDB, } \\
\text { DIARETDB, } \\
\text { MESSIDOR }\end{array}$ & & & $\begin{array}{l}\text { The algorithm } \\
\text { detected } \\
\text { Haemorrhages in } \\
551 \text { images out of } \\
561 \text { images giving } \\
\text { an accuracy of } \\
98.22 \%\end{array}$ & $\begin{array}{l}\text { The experimental } \\
\text { results show that the } \\
\text { detection of } \\
\text { Haemorrhages is } \\
\text { sufficiently accurate } \\
\text { and useful. Hence } \\
\text { this method may be } \\
\text { used for automatic } \\
\text { analysis of retinal } \\
\text { diseases. }\end{array}$ \\
\hline $\begin{array}{l}\text { K. Udaya } \\
\text { Bhaskar } \\
{[28]}\end{array}$ & $\begin{array}{l}\text { Luminosity } \\
\text { Contrast } \\
\text { normalization } \\
\text { pre- } \\
\text { processing, }\end{array}$ & $\begin{array}{c}\text { DIARET DB1 \& } \\
\text { DB0 } \\
\text { database }\end{array}$ & $\begin{array}{l}\text { Mean of blue } \\
\text { channel, mean of } \\
\text { green channel, } \\
\text { standard } \\
\text { deviation of red } \\
\text { channel, } \\
\text { Standard } \\
\text { deviation of blue } \\
\text { channel, } \\
\text { Mean of green } \\
\text { channel intensity, } \\
\text { Mean of blue } \\
\text { channel, Region } \\
\text { centroid in blue } \\
\text { channel, Region }\end{array}$ & $\begin{array}{c}\text { Multi- } \\
\text { Layered } \\
\text { Perceptr } \\
\text { on } \\
\text { (MLP), } \\
\text { Radial } \\
\text { Basis } \\
\text { Function } \\
\text { (RBF) } \\
\text { and } \\
\text { FLANN } \\
\text { classifie } \\
\text { r }\end{array}$ & $\begin{array}{l}\text { Propose method } \\
\text { having sensitivity of } \\
99 \% \text {, specificity of } \\
89 \% \text {, accuracy of } \\
94.7 \% \text {, }\end{array}$ & $\begin{array}{l}\text { FLANN classifier } \\
\text { has an advantage } \\
\text { over MLP and RBF } \\
\text { because FLANN } \\
\text { does not have any } \\
\text { hidden layer }\end{array}$ \\
\hline
\end{tabular}




\begin{tabular}{|c|c|c|c|c|c|c|}
\hline & & & $\begin{array}{l}\text { centroid in blue } \\
\text { channel, Color } \\
\text { difference of the } \\
\text { Red channel, } \\
\text { Color difference } \\
\text { of the green } \\
\text { channel, Color } \\
\text { difference of the } \\
\text { blue channel, } \\
\text { Region } \\
\text { compactness, } \\
\text { Homogeneity }\end{array}$ & & & \\
\hline $\begin{array}{l}\text { Ishita De, } \\
\text { Suchismit } \\
\text { a Das, } \\
\text { Debalina } \\
\text { Ghosh } \\
{[29]}\end{array}$ & CLAHE & & & & $\begin{array}{lr}\text { Proposed } & \text { method } \\
\text { gives } & \text { Specificity } \\
97.68 \%, & \text { Sensitivity } \\
70 \%, & \text { Accuracy } \\
95.42 \% & \end{array}$ & $\begin{array}{l}\text { The method is quite } \\
\text { good in terms of time } \\
\text { requirement. The } \\
\text { time taken for an } \\
\text { image in the Drive } \\
\text { database is less than } \\
\text { a minute. The time } \\
\text { required is less } \\
\text { because we use less } \\
\text { number of steps. } \\
\text { Another advantage } \\
\text { of the method is that } \\
\text { it does not require } \\
\text { the border masks } \\
\text { provided in the } \\
\text { database. So it can be } \\
\text { used for other retinal } \\
\text { image databases for } \\
\text { which the border } \\
\text { masks are not } \\
\text { provided. }\end{array}$ \\
\hline $\begin{array}{l}\text { Liu } \\
\text { Hongying } \\
\text { Juan, Fang } \\
\text { Qingli } \\
\text { [30] }\end{array}$ & $\begin{array}{l}\text { AAV2-EPO, } \\
\text { MHIS } \\
\text { (hyperspectral } \\
\text { imaging } \\
\text { system), } \\
\text { AOTF(Acoust } \\
\text { o-optic } \\
\text { Tunable } \\
\text { Filters), }\end{array}$ & & $\begin{array}{l}\text { Hyperspectral } \\
\text { image }\end{array}$ & & $\begin{array}{l}\text { The experimental } \\
\text { data } \\
\text { indicates that the } \\
\text { performance of } \\
\text { retinal ONL cells of } \\
\text { DR rats } \\
\text { can return to normal } \\
\text { levels after AAV2- } \\
\text { EPO middle dose } \\
\text { and digh dose treatment, } \\
\text { while AAV2-EPO } \\
\text { low dose treatment } \\
\text { can't effectively } \\
\text { restore the } \\
\text { performance of } \\
\text { retinal ONL cells } \\
\text { Of DR rats. }\end{array}$ & $\begin{array}{l}\text { the thickness of the } \\
\text { outer nuclear layer, } \\
\text { comparing the } \\
\text { relative error of the } \\
\text { spectrum and } \\
\text { spectral } \\
\text { Similarity } \\
\text { comparison. Which } \\
\text { helps us to confirm } \\
\text { which group of } \\
\text { E1E2E3 have the } \\
\text { optimal therapeutic } \\
\text { effect. }\end{array}$ \\
\hline $\begin{array}{l}\text { Jaykumar } \\
\text { Lachure, } \\
\text { A.V. } \\
\text { Deorankar } \\
\text { Sagar } \\
\text { Lachure, } \\
\text { Miss. } \\
\text { Swati } \\
\text { Gupta, } \\
\text { Romit } \\
\text { Jadhav } \\
\text { [31] }\end{array}$ & $\begin{array}{l}\text { Canny edge } \\
\text { detector, } \\
\text { GLCM, } \\
\text { multiclass } \\
\text { formulation }\end{array}$ & $\begin{array}{c}\text { Messidor, DB-rect } \\
\text { dataset, }\end{array}$ & $\begin{array}{l}\text { Structural } \\
\text { features, area, } \\
\text { local maxima, } \\
\text { red spot, energy, } \\
\text { contrast, entropy, } \\
\text { homogeneity, } \\
\text { Euclidian } \\
\text { distance }\end{array}$ & $\begin{array}{l}\text { SVM, } \\
\text { KNN }\end{array}$ & $\begin{array}{l}\text { specificity } \\
\text { is } 100 \% \text { and } \\
\text { sensitivity is more } \\
\text { than } 90 \% \text { for SVM. }\end{array}$ & $\begin{array}{l}\text { Proposed method } \\
\text { shows SVM } \\
\text { classifier is better } \\
\text { classifier than KNN. } \\
\text { So from the extracted } \\
\text { feature it directly } \\
\text { concludes the disease } \\
\text { grad as normal, } \\
\text { moderate and severe. }\end{array}$ \\
\hline $\begin{array}{l}\text { Surbhi } \\
\text { Sangwan, } \\
\text { Vishal } \\
\text { Sharma, } \\
\text { Misha } \\
\text { Kakkar } \\
{[32]}\end{array}$ & $\begin{array}{c}\text { Gradient } \\
\text { magnitude } \\
\text { segmentation, } \\
\text { fuzzy c } \\
\text { clustering, }\end{array}$ & & $\begin{array}{l}\text { Mean, sum of } \\
\text { ON pixels, area } \\
\text { of exudates, } \\
\text { edge, }\end{array}$ & SVM & \begin{tabular}{lr}
\multicolumn{3}{c}{ This paper provides } \\
a basis & of \\
classification & of \\
Normal, & \\
NPDR or & PDR \\
affected eye with \\
high accuracy \\
percentage \\
of $92.6 \%$.
\end{tabular} & $\begin{array}{l}\text { These results } \\
\text { strengthen the idea } \\
\text { that SVM can be } \\
\text { used efficiently and } \\
\text { effectively as a } \\
\text { classifier for } \\
\text { detecting eye related } \\
\text { diseases causes by } \\
\text { diabetic }\end{array}$ \\
\hline
\end{tabular}




\section{REFERENCES}

[1]. National Eye Institute, National Institutes of Health, "Diabetic Retinopathy: What you should know," Booklet, NIH Publication, No: 06-2171, 2003.

[2]. Jang Pyo Bae, Kwang Gi Kim, Ho Chul Kang, Chang Bu Jeong, Kyu Hyung Park, and Jeong-Min Hwang, "A Study on Haemorrhage Detection Using Hybrid Method in Fundus Images," Journal of Digital Imaging, Vol 24, No 3 (June), 2011: pp 394-404.

[3]. Giri Babu Kande, T. Satya Savithri, and P. Venkata Subbaiah, "Automatic Detection of Microaneurysms and Haemorrhages in Digital Fundus Images" Journal of Digital Imaging, Vol 23, No 4 (August), 2010: pp 430-437.

[4]. Bae JP, Kim KG, Kang HC, Jeong CB, Park KH, Hwang JM, "A Study on Haemorrhage Detection Using Hybrid Method in Fundus Image," J. Digital Image, vol. 24(3), pp. 394-404, June 2011.

[5]. Esmaeili M, Rabbani H, Dehnavi AM, Dehghani A, "A new curvelet transform based method for extraction of red lesions in digital color retinal images," in Proc. IEEE 17th Int. Conf. Image Processing, Hong Kong, pp. 4093-4096, September 2010.

[6]. X. Zhang and G. Fan, "Retinal Spot Lesion Detection Using Adaptive Multiscale Morphological Processing", in Proc. ISVC (2), pp. 490-501, 2006.

[7]. Matei, Daniela, and Radu Matei. "Detection of diabetic symptoms in retina images using analog algorithms." International Journal of Biological and Life Sciences 6.4 (2010): 224+. Health Reference Center Academic. Web. 25 Mar. 2010.

[8]. Langroudi, M.N., Sadjedi, H., "A New Method for Automatic Detection and Diagnosis of Retinopathy Diseases in Color Fundus Images Based on Morphology," Bioinformatics and Biomedical Technology (ICBBT), pp. 134 - 138,2010.

[9]. Acharya UR1, Lim CM, Ng EY, Chee C, Tamura T., "Computer-based detection of diabetes retinopathy stages using digital fundus images," Proceedings of the Institution of Mechanical Engineers, Part $\mathrm{H}$ : Journal of Engineering in Medicine July 1, 2009, 223: 545-553.

[10]. Marwan D Saleh and C. Eswaran, "An automated blood vessel extraction algorithm in fundus images," 2012 IEEE International conference on Bioinformatics and Bio-medicine,978-1-4673-2560-8/12, pg 482-486.

[11]. H. A. Hasan, N. M. Tahir, I. Yassin, A. Zabidi, C. H. C Yahaya, S. M. Shafie "Automated Optic Disc removal in fundus images using iterative heuristics and morphological operations," IEEE Conference on System, process \& control (ICSPC), 2013. pp. 230-233.

[12]. G.Ferdic Mashak Ponnaiah*, Capt. Dr. S. Santhosh Baboo, "Automatic optic disc detection and removal of hard exudate for improving retinopathy classification accuracy," International Journal of Scientific and Research Publications, Volume 3, Issue 3, March 2013, ISSN 2250-3153, pp. 1-7.

[13]. M. Niemeijer, B. Van Ginneken, M. J. Cree, A. Mizutani, G. Quellec, C. I. Sanchez, B. Zhang, R. Hornero, M. Lamard, C. Muramatsu, X. Wu, G. Cazuquel, J. You, A. Mayo, Q. Li, Y. Hatanaka, B. Cochener, C. Roux, F. Karray, M. Garcia, H. Fujita and M. D. Abramoff, "Retinopathy online challenge: Automatic detection of microaneurysms in digital color fundus photographs," IEEE Trans. Med. Imag., 2010, 29, 185-195.

[14]. L. Tang, M. Niemeijer, and M.D. Abrilmoff, "Splat feature classification: Detection of the presence of large retinal Haemorrhages," in Proc. ISBI, pp.681-684, 201.

[15]. J.J. Staal, MD. Abramoff, M. Niemeijer, M.A. Viergever, B. van Ginneken, "Ridgebased vessel segmentation in color images of the retina," IEEE Transactions on Medical Imaging, vol. 23, pp. 501-509, 2004.

[16]. D. Usher, M. Dumskyj, M. Himaga, T. H. Williamson, S. Nussey, and J. F. Boyce, "Automated detection of diabetic retinopathy in digital retinal images: a tool for diabetic retinopathy screening," Diabetic UK Diabetic Medicine, 21 (1), 8490, 2004.

[17]. García Rodríguez LA, Gaist D, GonzálezPérez A, Ashina M," Migraine and risk of hemorrhagic stroke: a study based on data from general practice." J Headache Pain 2014, 15:74. 10.1186/1129-2377-15-7

[18]. Malay Kishore Dutta, Shaumik Ganguly, Kshitij Srivastava, Shaunak Ganguly, M. Parthasarathi, Radim Burget, and Jan Masek," An Efficient Grading Algorithm for Non-Proliferative Diabetic Retinopathy using Region-Based Detection," TSP 2015, 
[19]. Saumitra Kumar Kuri, "Automatic Diabetic Retinopathy Detection Using Gabor Filter with Local Entropy Thresholding," IEEE 2nd International Conference on Recent Trends in Information Systems (ReTIS), 2015, pp. 411-415

[20]. Syna Sreng, Noppadol Maneerat, Don Isarakorn, Kazuhiko Hamamoto, "Automatic Haemorrhages Detection Based on Fundus Images," 2015 7th International Conference on Information Technology and Electrical Engineering (ICITEE), Chiang Mai, Thailand, pp 253-257.

[21]. Asra Ashraf, M. Usman Akram, Shahzad Amin Sheikh, "Detection of Retinal Whitening, Cotton Wool Spots and Retinal Haemorrhages for Diagnosis of Malarial Retinopathy,"

[22]. Jaykurnar Lachure, A. V. Deorankar, Mr. Sagar Lachure, Miss. Swati Gupta, Romit Jadhav, "Diabetic Retinopathy using Morphological Operations and Machine Learning," IEEE International Advance Computing Conference (IACC), 2015.

[23]. T. Ruba, K. Ramalakshmi, "Identification and segmentation of exudates using SVM classifier," IEEE Sponsored 2nd International Conference on Innovations in Information Embedded and Communication Systems, 2015

[24]. Amol Prataprao Bhatkar, Dr. G.U.Kharat, "Detection of Diabetic Retinopathy in Retinal Images using MLP classifier," 2015 IEEE International Symposium on Nanoelectronic and Information Systems, pp. 331- 335.

[25]. Vijay M Mane, Ramish B Kawadiwale, D. V. Jadhav, "Detection of Red Lesions in Diabetic Retinopathy Affected Fundus Images," IEEE International Advance Computing Conference (IACC), 2015

[26]. Syna Sreng, Noppadol Maneerat, Don Isarakorn, " Automatic Haemorrhages Detection Based on Fundus Images," International Conference on Information Technology and Electrical Engineering (ICTEE ), Chiang Mai, Thailand

[27]. Priyakshi Bharali, Jyoti Prakash Medhi, and Dr. S.R. Nirmala, "Detection of Haemorrhages in Diabetic Retinopathy analysis using Color Fundus Images," IEEE 2nd International Conference on Recent Trends in Information System (ReTIS) 2015

[28]. Udaya Bhaskar K, Pranay Kumar E.,"Extraction of hard exudates using functional link artificial neural networks,"
IEEE International Advance Computing Conference (IACC); 2015

[29]. Ishita De, Suchismita Das, Debalina Ghosh, "Vessel Extraction in Retinal Images using Morphological Filters," IEEE International Conference on Research on Computational Intelligence and Communication Networks, 2015

[30]. Liu Hongying, Fang Juan, Li Qingli, Zhang Jingfa, "Efficacy Evaluation of AAV2-EPO to Diabetic Retinopathy Based on Molecular Hyperspectral Imaging System", Seventh International Conference on Measuring Technology and Mechatronics Automation, IEEE 2015

[31]. Jaykumar Lachure, A.V. Deorankar, Sagar Lachure, Miss. Swati Gupta, Romit Jadhav, "Diabetic Retinopathy using Morphological Operations and Machine Learning" IEEE 2015

[32]. Surbhi Sangwan1, Vishal Sharma, Misha Kakkar, "Identification of Different Stages of Diabetic Retinopathy," 2015 International Conference on Computer and Computational Sciences (ICCCS) 